\title{
Knowledge and Use of Emergency Contraception: A Multicountry Analysis
}

\begin{abstract}
CONTEXT: Globally, evidence on knowledge and use of emergency contraception from population-based data is limited, though such information would be helpful in increasing access to the method. We examined knowledge and use of emergency contraception in 45 countries using population-based survey data.
\end{abstract}

METHODS: Demographic and Health Survey (DHS) data on women aged 15-49 were analyzed by country in logistic regressions to identify associations between women's characteristics and their having heard of emergency contraception or having ever used it. Trends were examined, by region and globally, according to individual, household and community descriptors, including women's age, education, marital status, socioeconomic status, and urban or rural location.

RESULTS: The proportion of women who had heard of emergency contraception ranged from 2\% in Chad to $66 \%$ in Colombia, and the proportion of sexually experienced women who had used it ranged from less than $0.1 \%$ in Chad to $12 \%$ in Colombia. The odds of having heard of or used the method generally increased with wealth, and although the relationship between marital status and knowing of the method varied by region, never-married women were more likely than married women to have used emergency contraception in countries where signifcant differences existed. In some countries, urban residence was associated with having heard of the method, but in only three countries were women from urban areas more likely to have used it.

CONCLUSIONS: Our findings support the need for broader dissemination of information on emergency contraception, particularly among low-income individuals. Variations in use and knowledge within regions suggest a need for programs to be tailored to country-level characteristics.

International Perspectives on Sexual and Reproductive Health, 2014,40(2):79-86, doi: 10.1363/4007914

Emergency contraception has been called "the best-kept secret" in reproductive health because, despite its unique potential for helping women prevent pregnancies and fulfill their reproductive intentions, rates of use and of counseling about the method are quite low. ${ }^{1}$ Since the introduction of dedicated emergency contraceptive pills in the mid-1990s, there has been relatively little research into the success of their introduction and uptake in developing countries. This lack of analysis on the use of emergency contraception has meant that little guidance is available about concrete strategies to expand access to the method. Even in such countries as Mexico, Kenya and Nigeria, which receive significant investment from donors, NGOs or governments for expanding access, relatively little documentation of programmatic strategies or evaluation of their impact exists. Most studies that assess patterns of emergency contraception knowledge and use in developing countries have been conducted on limited, nonrandom samples, rather than on population-based data. Studies in Ghana, Jamaica and Kenya sampled women purchasing the method in pharmacies, ${ }^{2-4}$ while studies in Honduras, Mexico, Egypt and China sampled women at health care facilities. ${ }^{5-10}$ Exceptions include population-based studies from individual cities in Nigeria and Kenya. ${ }^{11,12}$ The limited data available indicate that women with the highest rates of knowledge or use of emergency contraception are those with higher levels of education, ${ }^{2,5-8,11}$ those living in urban regions; ${ }^{6}$ and those who currently use, ${ }^{7,8,10}$ or have ever used, ${ }^{11}$ a modern contraceptive.

Because most existing studies are limited in their generalizability, we addressed gaps in knowledge by analyzing nationally representative data on emergency contraception from 45 countries in Africa, Asia, Europe and West Asia, and Latin America and the Caribbean. We investigate the proportion of women who have heard of emergency contraception and the proportion of sexually experienced women who have used it, and examine individual-, household- and community-level characteristics associated with having heard of or used the method. We hypothesize that more highly educated, wealthier, younger and urban women may have higher odds of having heard of and having used emergency contraception than other women.

\section{METHODS \\ Data and Sample}

Data used in this analysis come from Demographic and Health Surveys (DHS), population-level household surveys that provide high-quality data for a wide range of
By Tia Palermo, Jennifer Bleck and Elizabeth Westley

Tia Palermo is assistant professor, Program in Public Health, Department of Preventive Medicine, Stony Brook University, State University of New York. Jennifer Bleck is doctoral candidate, Department of Community and Family Health, College of Public Health, University of South Florida. Elizabeth Westley is coordinator, International Consortium for Emergency Contraception, Family Care International, New York. 
indicators related to population, health and nutrition. For our analysis, we used data from the 45 countries whose most recent survey occurred between 2000 and 2012 and included information on emergency contraception. * Since 1999, questions about emergency contraception have been included in the women's questionnaire, which is typically administered to all women aged 15-49 and contains questions related to fertility, sexual behavior and family planning. In some countries in our analysis, however, only ever-married women are asked fertility- and sex-related questions (Egypt, Indonesia, Jordan, the Maldives, Pakistan and Turkey). Analyses of knowledge of emergency contraception included the full sample of respondents to whom the women's questionnaire was administered, while analyses of emergency contraception use included only women who reported ever having had sex.

\section{Measures}

The primary outcomes of interest in this study were women's having heard of and having ever used emergency contraception. DHS interviewers first asked women what methods of family planning they had heard about. They then asked about specific methods not spontaneously mentioned by the woman, using locally known terms. Emergency contraception was referred to as the "morning-after pill" and by locally available brand names. For each method for which the woman indicated knowledge, including emergency contraception, the respondent was then asked whether she had ever used that method.

The independent variables used in this analysis were individual-level characteristics (age, marital status and educational attainment), household-level wealth and community-level characteristics (urban or rural location and region). Marital status was categorized as currently married (or in union), never married and formerly married (widowed, divorced or separated). Age was categorized in five-year increments, beginning with 15-19. Education was broken into less than primary (no education or incomplete primary education), complete primary, and some secondary or higher education. Household wealth was divided into quintiles (poorest, poor, middle, rich, richest). ${ }^{\dagger}$

\section{Statistical Analysis}

We described percentages of women reporting knowledge and use of emergency contraception by country and sample characteristics. To investigate characteristics independently associated with having heard of and having used emergency contraception, we ran country-specific multivariate logistic models, using knowledge and use of the method as separate outcome variables and controlling for all individual-, household- and community-level variables. ${ }^{*}$ Appropriate sample weights were used, and all analyses accounted for complex survey design. We combined categories of independent variables where rates of usage were too low in any one category (see tables for details). In the cases of Armenia, Moldova and Ukraine, it was not possible to include education in the multivariate regression models because of the lack of variability in educational achievement in these countries. In preliminary analyses, we tested differences by religion but found few significant differences and therefore eliminated religion indicators to achieve more parsimonious models and increased comparability across countries.

\section{RESULTS}

\section{Global and Regional Overview}

The proportion of women who had heard of emergency contraception was highest in Colombia (66\%) and Ukraine (49\%) and lowest in Chad (2\%) and Timor-Leste (3\%; Table 1). Among women who had ever been sexually active, the proportion reporting having ever used emergency contraception ranged from less than $0.1 \%$ in Chad to $12 \%$ in Colombia.

Knowledge and use of the method varied considerably within regions. In Africa, awareness of emergency contraception ranged from $2 \%$ (Chad) to $40 \%$ (Kenya), and among sexually experienced women, the proportion who reported ever having used emergency contraception ranged from less than $0.1 \%$ (Chad) to $4 \%$ (Ghana). In Asia, the proportion of women who had heard of emergency contraception ranged from 3\% (Timor-Leste) to 29\% (the Maldives), and usage rates among ever-sexually active women ranged from $0.1 \%$ (Cambodia, Nepal and TimorLeste) to $0.9 \%$ (Pakistan). In Europe and West Asia, the proportion of women who had heard of emergency contraception ranged from 5\% (Azerbaijan) to 49\% (Ukraine), and rates of use among ever-sexually active women ranged from less than 1\% (Azerbaijan) to 6\% (Ukraine). And in Latin America and the Caribbean, the proportion of women who had heard of emergency contraception ranged from 13\% (Haiti) to 66\% (Colombia), and rates of use among ever-sexually active women ranged from less than $1 \%$ (Haiti) to $12 \%$ (Colombia).

\section{Africa}

-Knowledge and women's characteristics. Compared with currently married women, never-married women had lower odds of having heard of emergency contraception in eight of 24 countries (odds ratio range, 0.5 in Mali to 0.8 in Namibia), while formerly married women had elevated odds of having heard of it in two of 24 countries,

*Although data from Congo-Brazzaville met the criteria for inclusion they were not used because of issues with credibility of the estimates of reported knowledge and use of emergency contraception. Rates of knowledge and use were two and 10 times as high, respectively, as the average rates from other African countries, with the reported usage rate nearing that of such developed countries as the United States and France.

tWealth indicators were not available in the DHS data for Nicaragua, so we created our own using a household standard of living score that combined measures for assets and amenities using principal components analysis (source: Filmer D and Pritchett LH, Estimating wealth effects without expenditure data-or tears: an application to educational enrollments in states of India, Demography, 2001, 38(1):115-132).

‡Rates of emergency contraception use were too low to analyze individually in logistic regression models in Azerbaijan, Cambodia, Chad Egypt, Guinea, Nepal, Niger, Rwanda, Senegal, Timor-Leste and Uganda. 
Benin (1.4) and Liberia (1.9; Web Appendix Tables 1 and 2); see www.guttmacher.org/pubs/journals/40007914. pdf. In Swaziland, however, never-married women were significantly more likely than currently married women to have heard of the method (1.5).

Generally, older women were more likely than 15-19-year-olds to be aware of emergency contraception, especially in Southern Africa and Egypt, although there was no relationship between knowledge and age in Liberia. Odds ratios ranged from 1.4 among 30-34-year-olds in Namibia to 4.9 among 35-39-year-olds in Chad. Having heard of emergency contraception was positively associated with education: Odds ratios ranged from 1.2 in Malawi to 6.4 in Chad for those who had completed primary school and from 1.6 in Ghana to 10.4 in Chad for those who had had some secondary or higher education, compared with those who had had less than a complete primary education. The odds of having heard of emergency contraception also increased with wealth for most African countries, though the difference was small in some, and no differences by wealth status existed in Mali and Niger. Knowledge of emergency contraception was significantly higher among women in urban areas than among those in rural areas in Democratic Republic of Congo (1.6), Madagascar (1.3) and Niger (3.4); in Chad, that association was reversed (0.3).

- Use and women's characteristics. Among women who had ever had sex, use of emergency contraception generally increased with education: Compared with women with less than a primary education, those with some secondary or higher education had elevated odds of use in 12 of the 17 countries analyzed according to this outcome (range, 1.7 in Cameroon to 5.7 in Swaziland; Web Appendix Tables 3 and 4). The relationship between wealth and use of the method was much less pronounced than that between wealth and knowledge. In 10 African countries, there were no differences in use of emergency contraception by wealth, and in the seven countries with significant differences, only women in the top or top two wealth categories had higher odds of having used emergency contraception than those in the poorest category. In three countries, women in urban areas were more likely to have used the method than those in rural areas (range, 2.8 in Madagascar to 6.9 in Burkina Faso).

\section{Asia}

Unmarried women in Indonesia, the Maldives and Pakistan were not asked about contraceptive knowledge and use. In the other five Asian countries in our sample, compared with married women, never-married women were less likely to know of emergency contraception in three countries (odds ratio range, 0.01 in Nepal to 0.6 in TimorLeste) and more likely to know about it in the Philippines (1.4; Web Appendix Table 5). Older women were more likely than 15-19-year-olds to know of emergency contraception, except in Nepal, where there were no differences, and in the Maldives, where only 45-49-year-olds had elevated odds of having heard of it (1.4). Compared with

TABLE 1. Number and proportion of all women aged 15-49 who had heard of emergency contraception, and number and proportion of sexually experienced women in that age-group who had ever used the method, by region and country

Country (survey year)

All women

Sexually experienced women

$\mathrm{N} \quad \begin{aligned} & \text { \% heard of } \\ & \text { method }\end{aligned} \quad \mathrm{N} \quad \begin{aligned} & \text { \% ever used } \\ & \text { method }\end{aligned}$

\section{Africa}

Benin (2006)

Burkina Faso (2003)

Cameroon (2004)

Chad (2004)

DRC (2007)

Egypt (2008)*

Ghana (2008)

Guinea (2005)

Kenya (2008-2009)

Liberia (2007)

Madagascar (2008-2009)

Malawi (2010)

Mali (2006)

Namibia (2006-2007)

Niger (2006)

Nigeria (2008)

Rwanda (2005)

Sao Tome and Principe (2008-2009)

Senegal (2005)

Sierra Leone (2008)

Swaziland (2006-2007)

Uganda (2006)

Zambia (2007)

Zimbabwe (2005-2006)

Asia

Cambodia (2005)

India (2005-2006)

Indonesia (2007)*

Maldives (2009)*

Nepal (2006)

Pakistan (2006-2007) ${ }^{*}, \dagger$

Philippines (2008)

Timor-Leste (2009)

Europe and West Asia

Albania (2008-2009)

Armenia (2005)

Azerbaijan (2006)

Jordan (2007)*,

Moldova (2005)

Turkey (2003)*

Ukraine (2007)

Latin America and the Caribbean

Bolivia (2008)

Colombia (2010)

Dominican Republic (2007)

Haiti (2005-2006)

Honduras (2005-2006)

Nicaragua (2001)

\section{7,664}

12,466

10,604

6,083

9,958

16,507

4,876

7,917

8,424

7,045

17,346

22,929

14,518

9,738

9,195

33,141

11,294

2,613

14,546

7,358

4,960

8,510

7,138

8,872

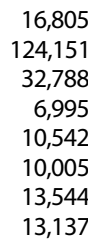

16,805

24,151

6,995

10,542

10,005

13,544
13,137

(2)

$\begin{array}{rr}10.9 & 14, \\ 9.4 & 10,2 \\ 18.5 & 8,8 \\ 1.6 & 5,120 \\ 11.1 & \end{array}$

$\begin{array}{rr}14,756 & 1.0 \\ 10,200 & 0.5 \\ 8,889 & 3.0 \\ 5,120 & <0.1 \\ 8,201 & 1.3 \\ 16,507 & 0.1 \\ 3,877 & 3.5 \\ 6,615 & 0.3 \\ 6,479 & 2.1 \\ 6,246 & 3.4 \\ 14,930 & 0.6 \\ 18,607 & 0.9 \\ 12,109 & 0.3 \\ 7,482 & 2.0 \\ 7,515 & 0.1 \\ 26,319 & 3.4 \\ 7,536 & 0.1 \\ 2,190 & 0.5 \\ 10,025 & 0.2 \\ 6,098 & 1.3 \\ 3,740 & 3.4 \\ 6,991 & 0.4 \\ 5,744 & 0.6 \\ 6,708 & 1.9\end{array}$

*Ever-married women only. Information about ever having had sex not available; use category includes al ever-married women. Note:DRC=Democratic Republic of Congo.

women with less than a primary education, those who had completed primary school were more likely to know about emergency contraception in four countries (range, 1.3 in the Maldives to 1.8 in Nepal), and those with some secondary or higher education were more likely to know about emergency contraception in all Asian countries studied (range, 1.5 in Cambodia to 3.1 in Nepal). The proportion of women who had heard of the method generally rose with wealth, but the relationship was very weak in 
the Maldives. Only in India were urban women more likely than rural women to have heard of emergency contraception (1.2).

In Asia, there were no differences by marital status in the odds of having ever used emergency contraception. Sexually experienced women aged 25-39 were more likely than those aged 15-19 to have used the method in India (odds ratios, 5.9-6.0), but in the Philippines, women aged 20-24 (0.1), 35-39 (0.2) and 45-49 (0.2) were less likely than those aged 15-19 to have used it. Increased education was associated with use only in India, where those who had completed primary school (2.1) or had some secondary or higher education (1.7) were more likely to have used emergency contraception than those who had less than a primary education. Use was associated with wealth only in India and Pakistan, and there were no differences in use by urban or rural location.

\section{Europe and West Asia}

Knowledge varied by marital status only in Armenia, where never-married women were less likely than married women to have heard of the method (odds ratio, 0.6; Web Appendix Table 6). Compared with those in the youngest age-group (the definition of which varied by country), older women were more likely to have heard of the method in all study countries except for Turkey, where women aged 30-34 had reduced odds of having heard of the method (0.7). Differences by educational status were not assessed for Armenia, Moldova and Ukraine, but in Albania, Jordan and Turkey, women with some secondary or higher education were more likely than those with less than a primary education to have heard of emergency contraception (range, 1.4 in Jordan to 3.0 in Albania). The odds of having heard of the method increased with household wealth in Albania, Armenia, Azerbaijan, Moldova, Turkey and Ukraine, but not in Jordan. There were no differences in knowledge of emergency contraception by urban or rural location.

Among sexually experienced women, those who had never been married were more likely than currently married women to have ever used emergency contraception in three countries (range, 1.8 in Ukraine to 25.7 in Armenia); formerly married women were more likely to have used the method in Ukraine only (1.9). Only in Jordan was age strongly associated with use: Compared with women aged 15-24, older women had odds of use ranging from 12.1 to 28.8. In Jordan, women who had completed primary school were less likely to have used emergency contraception than those who had not (0.1), and there were no differences by education level in Albania or Turkey; differences in use by educational attainment were not examined in Armenia, Azerbaijan, Moldova or Ukraine. The likelihood of having used emergency contraception rose with wealth in Albania, Jordan, Moldova and Ukraine, but not in Armenia or Turkey. Only in Ukraine were urban women more likely than women in rural areas to have used the method (1.6)

\section{Latin America and the Caribbean}

In this region, compared with currently married women, never-married women were more likely to have heard of the method in Bolivia (odds ratio, 1.7) and Colombia (1.2) and less likely to have done so in the Dominican Republic (0.8) and Haiti (0.5; Web Appendix Table 7). Increasing age was positively associated with having heard of emergency contraception, though this relationship was relatively weak in Nicaragua. Compared with women with less than a primary education, those with a complete primary education were more likely to have heard of the method (1.3-1.4 for each of the four countries showing a significant association), as were those with some secondary or higher education (range, 2.0 in Haiti to 3.6 in Bolivia). There was a clear positive relationship between wealth and knowing of emergency contraception, except in Haiti, where only the women in the two richest wealth quintiles had elevated odds of having heard of the method. Only in the Dominican Republic and Nicaragua were women in urban areas more likely than those in rural areas to have heard of it (1.2 and 1.3, respectively).

The odds of having ever used emergency contraception were generally higher among sexually experienced nevermarried women (odds ratio range, 1.8 in Honduras to 2.2 in Colombia) and formerly married women (range, 1.4 in the Dominican Republic to 3.5 in Haiti) than among currently married women. There was little difference in use by age in Haiti and none in Honduras, while in Bolivia and Colombia, women aged 20-24 were more likely than 15-19-year-olds to have used emergency contraception (2.5 and 1.5, respectively). Women aged 25-29 had elevated odds of having used the method in Bolivia (2.0); in Colombia, the Dominican Republic and Nicaragua, however, women in some older age-groups were less likely than those aged 15-19 to have used it. Women who had completed a primary education were more likely than those who had not to have used emergency contraception in Bolivia (2.7), and in all countries except Haiti and Nicaragua, women with some secondary or higher education had elevated odds of having used it (range, 2.1 in Bolivia to 2.7 in Colombia). Use of the method increased with wealth in Colombia and Honduras, but only the richest women were more likely than the poorest to have used it in Bolivia, the Dominican Republic and Haiti. There were no differences in this region in use by urban or rural residence.

\section{DISCUSSION}

Overall, rates of having heard of or used emergency contraception were low in the countries studied. In 36 of the 45 countries, the rate of use was less than 3\% among women who had ever had sex. This evidence is contrary to claims in some settings that use of the method is widespread. For instance, media reports of overuse in India and Kenya are not supported by the relatively low levels of use we found in those countries. ${ }^{13-15}$

Rates of emergency contraception use in the countries studied were generally much lower than in countries 
where the method has been on the market for longer. For example, in France and the United States, approximately $17 \%$ and $11 \%$, respectively, of all women aged $15-44$ have used emergency contraception. ${ }^{16,17}$ In our study, Colombia stood out as the exception. Several factors probably account for Colombia's relatively high usage rate of $12 \%$, including the country's overall high rate of modern contraceptive use ( $73 \%$ among married women ${ }^{18}$ ), high levels of human development (including high levels of literacy and access to media), ${ }^{19}$ and a relatively unimpeded commercial sector that provides nine brands of emergency contraception. Furthermore, Colombia's DHS (along with Malawi's) was the most recent survey included in our analysis (2010), and we expect use may increase annually for some time following initial introduction.

Our results also revealed some patterns in rates of knowledge and use by region. In general, rates of emergency contraception use were lowest in Asia and Africa; 16 of the 17 countries with the lowest usage rates were in these regions (the exception was Haiti). No Asian country was in the top half of countries studied when ranked according to usage rate, while several African countries (Cameroon, Ghana, Liberia, Nigeria and Swaziland) ranked among the top half. Africa and Asia have the highest total fertility rates of the regions studied, so lower rates of emergency contraception use in these areas may reflect a combination of preference for large families, ambivalence regarding pregnancy prevention or a lack of access to contraceptive methods generally. However, aside from the 17 countries ranked lowest in terms of usage rates, the overall rankings are relatively mixed by region, suggesting that countrylevel factors are also influential.

In addition, our results point to socioeconomic inequalities in knowledge and access to emergency contraception: The odds of having heard of and having used the method generally rose as education and wealth increased. In Africa, we saw pronounced differences in knowledge by both educational attainment and wealth and in use by educational attainment. This may suggest that demand-side factors are at play. In Asia, where ever-use was lowest overall, richer women in both Pakistan and India (though not in Indonesia, the Maldives or the Philippines) were much more likely than the poorest women to have used it. A more consistent pattern with respect to socioeconomic status emerged in Latin America and the Caribbean (with the exception of Nicaragua), and a similar pattern emerged in four of the six countries studied in Eastern Europe and West Asia.

Other results of note include those related to urban or rural location and marital status. Differences by location were not found for either knowledge or use in most countries, but of those countries with significant associations, women in urban areas were more likely to know about and to have used emergency contraception (with the exception of women in Chad, who also had the lowest rates of use of any country surveyed). Results regarding marital status varied by region. A general pattern was that never-married women were less likely than married women to know about the method (except in Latin America, where results were mixed, and in Swaziland and the Philippines, where never-married women were more likely than currently married women to know of the method).

Patterns of emergency contraception use differed from patterns of knowledge, however. Where significant differences existed, never-married and formerly married women were typically more likely to have used the method than were married women (with the exception of never-married women in Zimbabwe). This pattern held for Latin America and Eastern Europe and Central Asia, but among the 17 African countries studied, never-married and formerly married women were more likely to have used emergency contraception in only three and four countries, respectively. In Asia, we could compare never-married women to currently and formerly married women in only two countries (India and the Philippines), and we found no differences in use by marital status.

Finally, regression results showed that only in Turkey did adolescents have higher rates of knowledge than adult women; the reverse was true in many countries. Fewer agerelated differences emerged in analyses of use. In Bolivia, Ghana, India, Jordan, Nigeria and Swaziland, older women were more likely to have used emergency contraception than women aged 15-19. However, in the Philippines and Nicaragua, and among women in one age-group in Sierra Leone, older women were less likely than younger women to have used it, despite older women's higher odds of having heard of the method. That younger women were typically more likely to have heard of emergency contraception, while older women were more likely to have used it is a pattern that can likely be attributed to the different samples on which regressions were run: Having ever used the method was assessed for all women, whereas use was examined only among those who had ever had sex.

It is important to note that emergency contraception use at the individual level is affected by supply, which is influenced by such macro-level factors as registration and availability of brands in the country, pharmacists' willingness to provide the method, and procurement of the method by large international organizations, such as the United Nations Population Fund. Several countries studied do not have registered emergency contraception products available, but some women and health providers may employ the Yuzpe regimen, which involves taking a higher-thannormal dose of regular birth control pills.

In some countries, political and religious opposition has hindered registration of a dedicated emergency contraception product. In the Philippines, for example, the only dedicated product was removed from the list of approved drugs in 2001. Yet the Philippines has since been found to have higher rates of emergency contraception use than Indonesia, which was one of the first countries where a dedicated method was introduced and where it has remained on the market (albeit with little continuing investment) for close to two decades. This suggests that emergency contraception is available in the Philippines on the black mar- 
ket. In Honduras, where political opposition to emergency contraception has been pronounced, health professionals in the capital city have expressed concern about the lack of access to the method, while acknowledging that it may be available on the black market at a high price. ${ }^{20}$ Some other countries with among the lowest rates of emergency contraception use found in our study (Haiti, Jordan, Maldives, Rwanda, Sao Tome and Principe, and Timor-Leste) do not have a registered product, but there is evidence that NGOs may have brought emergency contraception into these countries on a project-specific basis. These countries are small and many have recently been affected by crises and unrest; therefore they may not be seen as fruitful markets for commercial emergency contraceptive products.

We were able to obtain data on year of the first emergency contraception product registration for 15 of the countries studied, and when we examined the relationship between year of registration and rates of emergency contraception use, we found that countries with products registered earlier had higher rates of use, with the exception of Colombia, which had the latest registration (2005) but the highest rate of use, likely due to characteristics discussed above.

Another factor that presumably influences having heard of and having used emergency contraception is social marketing. Emergency contraceptive products were socially marketed in eight of the 45 studied countries at the time of survey, ${ }^{21}$ but there was no discernible correlation between social marketing and usage rates, according to our analysis, and social marketing by small NGOs may be missed in the available statistics. Furthermore, within countries, there may be regional differences in method availability.

A strength of our regional fixed-effects modeling approach (i.e., using regional dummies within countries) is that it controls for unobserved characteristics at the regional level, such as differences in provider training levels, supply, health facility infrastructure, transportation to points of care and so on. However, our analyses have some limitations. Demographic and Health Surveys are conducted infrequently-every five years at best-and there is a delay in the release of the data, so to capture as many countries as possible, we chose to include surveys conducted between 2000 and 2010. It is probable that more recent surveys would show higher rates of knowledge and use of emergency contraception. In addition, the questions asked about each contraceptive method are limited to everuse and current use, and more detailed information, such as frequency of emergency contraception use, cannot be gleaned from these surveys. Finally, because of endogeneity issues inherent in the estimation of this relationship, we do not test whether current use of a modern contraceptive method is associated with emergency contraception use.

\section{Conclusion}

This study helps fill important gaps in knowledge surrounding who knows about and is using emergency contraception globally, and our results suggest some pro- grammatic and policy recommendations. Given the extremely low rates of awareness of emergency contraception in many of the countries studied, programs should focus on disseminating accurate information about the method, both in the general population and in vulnerable groups and those identified in our study as being unlikely to have heard of it. Our findings that women of low socioeconomic status and those in rural areas may have reduced access to the method suggest that family planning programs and social marketing campaigns should focus on these groups to improve equity, as the commercial sector may not be motivated to reach poorer customers. A range of stakeholders have an important part to play in increasing knowledge and access to family planning methods. Governments, donors, the commercial sector and the nongovernmental sector should renew their focus on including emergency contraception as part of the contraceptive method mix in order to meet the reproductive health needs of women in developing countries. Policy recommendations include strengthening weak health systems that inhibit access to contraceptive methods, ${ }^{22}$ ensuring that emergency contraception commodities are available at public-sector health facilities, and removing laws that require prescription-only access to the method or that restrict access for young women; these policies may affect use and demand even among women who know about the method.

Future studies should provide more detailed investigations of social, cultural and economic factors at work in these countries to fully make sense of differences, particularly by age and marital status, identified in our study. Case studies might also be useful in describing how countries such as Liberia and Nigeria achieved usage above 3\%, despite low levels of development. What factors are at play in these countries that can help explain why more-developed countries with higher contraceptive prevalence rates, such as Rwanda and Senegal, have much lower rates of emergency contraception use? A more in-depth examination of supply- and demand-related issues in these countries can help programs reach a greater proportion of women and assist them in meeting their contraceptive needs.

\section{REFERENCES}

1. Coeytaux F and Pillsbury B, Bringing emergency contraception to American women: the history and remaining challenges, Women's Health Issues, 2001, 11(2):80-86.

2. L'Engle KL, Hinson L and Chin-Quee D, "I love my ECPs:" challenges to bridging emergency contraceptive users to more effective contraceptive methods in Ghana, Journal of Family Planning and Reproductive Health Care, 2011, 37(3):146-151.

3. Chin-Quee DS, Cuthbertson C and Janowitz B, Over-the-counter pill provision: evidence from Jamaica, Studies in Family Planning, 2006, 37(2):99-110

4. Keesbury J, Morgan G and Owino B, Is repeat use of emergency contraception common among pharmacy clients? Evidence from Kenya Contraception, 2011, 83(4):346-351.

5. Smit J et al., Emergency contraception in South Africa: knowledge, attitudes, and use among public sector primary healthcare clients, Contraception, 2001, 64(6):333-337.

6. Myer L et al., Knowledge and use of emergency contraception 
among women in the Western Cape province of South Africa: a crosssectional study, BMC Women's Health, 2007, 7(1):14.

7. Langer A et al., Emergency contraception in Mexico City: what do health care providers and potential users know and think about it? Contraception, 1999, 60(4):233-241.

8. García SG et al., Emergency contraception in Honduras: knowledge, attitudes, and practice among urban family planning clients, Studies in Family Planning, 2006, 37(3):187-196.

9. Shaaban OM et al., Emergency contraception in the context of marriage in Upper Egypt, International Journal of Gynaecology \& Obstetrics, 2011, 112(3):195-199.

10. Meng CX et al., Emergency contraceptive use among 5,677 women seeking abortion in Shanghai, China, Human Reproduction, 2009, 24(7):1612-1618.

11. Obi SN and Ozumba BC, Emergency contraceptive knowledge and practice among unmarried women in Enugu, southeast Nigeria, Nigerian Journal of Clinical Practice, 2008, 11(4):296-299.

12. Chin-Quee DS and L'Engle KL, Frequency and context of EC use in urban Kenya and Nigeria, paper presented at EC Jamboree 2012, New York, Oct. 5, 2012

13. Jena $\mathrm{M}$, India: rising use of emergency contraceptives raises alarm, Inter Press Service News Agency, May 21, 2010, <http://www.ipsnews. net/2010/05/india-rising-use-of-emergency-contraceptives-raisesalarm/>, accessed Jan. 24, 2014

14. Mawathe A, Kenya concern over pill popping, BBC News, July 14 , 2009, <http://news.bbc.co.uk/2/hi/africa/8145418.stm>, accessed Jan. 24,2014

15. Rai S, India: popping morning after pills like candy, MinnPost, June 29, 2010, <http://www.minnpost.com/global-post/2010/06/indiapopping-morning-after-pills-candy>, accessed Jan. 24, 2014.

16. Daniels K, Jones J and Abma J, Use of emergency contraception among women aged 15-44: United States, 2006-2010, NCHS Data Brief, 2013, No. 112.

17. Moreau C, Bajos N and Trussell J, The impact of pharmacy access to emergency contraceptive pills in France, Contraception, 2006, 73(6):602-608.

18. PRB, 2013 World Population Data Sheet, Washington, DC: PRB, 2013.

19. United Nations Development Programme (UNDP), Human Development Report 2013: The Rise of the South: Human Progress in a Diverse World, New York: UNDP, 2013.

20. Padilla K, Ipas Central America, personal communication, Jan. 27, 2014.

21. DKT International, 2012 Contraceptive Social Marketing Statistics, Washington, DC: DKT International, 2013.

22. Foreman M and Spieler J, Contraceptive Evidence: Questions and Answers, Washington, DC: PRB, 2013.

\section{RESUMEN}

Contexto: A nivel mundial, la evidencia acerca de los conocimientos y el uso de anticoncepción de emergencia a partir de datos poblacionales es limitada, a pesar de que dicha información sería útil para aumentar el acceso al método. Examinamos datos sobre los conocimientos y el uso de anticoncepción de emergencia en 45 países, usando como base encuestas de población.

Métodos: Mediante regresiones logísticas, se analizaron datos por país obtenidos de Encuestas Demográficas y de Salud (EDS), referentes a mujeres en edades entre 15 y 49 años con el fin de identificar las asociaciones entre las características de las mujeres y el hecho de que hubieran escuchado acerca de la anticoncepción de emergencia o que la hubieran usado algu- na vez. Se examinaron tendencias, con un enfoque regional y mundial, basándose en descriptores a nivel de individuos, hogares y comunidades, incluyendo la edad, la educación, el estado conyugal, la condición socioeconómica, así como la ubicación rural o urbana de las mujeres.

Resultados: La proporción de mujeres que habian escuchado acerca de la anticoncepción de emergencia varió entre un $2 \%$ en Chad a un 66\% en Colombia, y la proporción de mujeres con experiencia sexual que la habian usado varió de un $0.04 \%$ en Chad a un $12 \%$ en Colombia. La probabilidad de haber escuchado acerca del método o de haberlo usado generalmente aumentó con el nivel de riqueza; aunque la relación entre el estado conyugal y el conocimiento sobre el método varió por región, las mujeres que nunca habían estado casadas tuvieron más probabilidades que las mujeres casadas de haber usado anticoncepción de emergencia en países donde existieron diferencias significativas. En algunos países, residir en una zona urbana se asoció con el hecho de haber escuchado sobre el método, pero solamente en tres países las mujeres que residian en zonas urbanas tuvieron mayor probabilidad de haberlo usado.

Conclusiones: Nuestros hallazgos apoyan la necesidad de una mayor difusión de la información sobre la anticoncepción de emergencia, dirigida particularmente a personas de más bajos ingresos. Las variaciones en uso y conocimientos dentro de las regiones sugieren la necesidad de que los programas se diseñen de acuerdo con las características de cada país; y las investigaciones futuras deberían aportar estudios de caso de países con los más altos niveles de aceptación del método, para destacar las mejores prácticas.

\section{RÉSUMÉ}

Contexte: À l'échelle mondiale, l'évidence obtenue de données de population concernant la connaissance et l'usage de la contraception d'urgence est limitée. Cette information serait pourtant utile à l'amélioration de l'accès à la méthode. Nous avons examiné ces facteurs dans 45 pays sur la base de données d'enquêtes en population.

Méthodes: Les données d'EDS (Enquête démographique et de santé) relatives aux femmes âgées de 15 à 49 ans ont été analysées par pays, par régression logistique, afin d'identifier les associations entre les caractéristiques des femmes et leur sensibilisation ou recours éventuel à la contraception d'urgence. Les tendances ont été examinées, par région et à l'échelle mondiale, en fonction de descripteurs individuels, de ménage et de communauté, notamment l'âge, le niveau d'éducation, l'état matrimonial, le statut socioéconomique et le lieu de résidence urbain ou rural des fermmes.

Résultats: La proportion des femmes qui avaient entendu parler de la contraception d'urgence varie entre $2 \%$ au Tchad et $66 \%$ en Colombie et celle des femmes sexuellement expérimentées qui y avaient eu recours, entre 0,04\% au Tchad et $12 \%$ en Colombie. La probabilité d'avoir entendu parler de la méthode ou d'y avoir eu recours augmente généralement avec la richesse et, bien que le rapport entre l'état matrimonial et la sensibilisation à la méthode varie d'une région à l'autre, les femmes qui n'avaient jamais été mariées sont plus 
susceptibles que celles mariées d'avoir utilisé la contraception d'urgence dans les pays présentant une différence significative. Dans certains pays, le lieu de résidence urbain est associé à la sensibilisation à la méthode, mais les femmes urbaines ne sont plus susceptibles d'y avoir eu recours que dans trois pays. Conclusions: Nos observations s'inscrivent au soutien d'une plus large dissémination de l'information sur la contraception d'urgence, en particulier auprès des personnes à moindres revenus. Les variations du recours et de la connaissance au sein des régions laissent entendre la nécessité d'adaptation des programmes aux caractéristiques de chaque pays.

Author contact: tia.palermo@stonybrook.edu 
WEB APPENDIX TABLE 1. Odds ratios (and 95\% confidence intervals) from logistic regression analyses assessing associations between women's characteristics and having heard of emergency contraception, Eastern and Southern Africa and Egypt

\begin{tabular}{|c|c|c|c|c|c|c|c|c|c|c|}
\hline Characteristic & Egypt† & Kenya & Madagascar & Malawi & Namibia & Rwanda & Swaziland & Uganda & Zambia & Zimbabwe \\
\hline \multicolumn{11}{|l|}{ Marital status $¥$} \\
\hline Currently married (ref) & 1.00 & 1.00 & 1.00 & 1.00 & 1.00 & 1.00 & 1.00 & 1.00 & 1.00 & 1.00 \\
\hline \multirow[t]{2}{*}{ Never married } & na & 0.85 & $0.73^{*}$ & $0.54^{* * *}$ & $0.77^{* *}$ & $0.74^{*}$ & $1.46^{* * *}$ & 0.79 & 1.17 & $0.70^{* *}$ \\
\hline & na & $(0.69-1.05)$ & $(0.56-0.95)$ & $(0.46-0.63)$ & $(0.64-0.92)$ & $(0.57-0.96)$ & $(1.23-1.73)$ & $(0.61-1.02)$ & $(0.85-1.61)$ & $(0.55-0.89)$ \\
\hline Formerly married & $\begin{array}{l}1.24 \\
(0.89-1.73)\end{array}$ & $\begin{array}{l}1.10 \\
(0.86-1.41)\end{array}$ & $\begin{array}{l}1.00 \\
(0.83-1.22)\end{array}$ & $\begin{array}{l}1.00 \\
(0.90-1.12)\end{array}$ & $\begin{array}{l}0.87 \\
(0.64-1.20)\end{array}$ & $\begin{array}{l}0.89 \\
(0.71-1.12)\end{array}$ & $\begin{array}{l}0.92 \\
(0.63-1.35)\end{array}$ & $\begin{array}{l}0.96 \\
(0.77-1.20)\end{array}$ & $\begin{array}{l}1.23 \\
(0.93-1.62)\end{array}$ & $\begin{array}{l}0.97 \\
(0.81-1.17)\end{array}$ \\
\hline \multicolumn{11}{|l|}{ Age } \\
\hline $15-19$ (ref) & 1.00 & 1.00 & 1.00 & 1.00 & 1.00 & 1.00 & 1.00 & 1.00 & 1.00 & 1.00 \\
\hline \multirow[t]{2}{*}{$20-24$} & $2.01^{*}$ & $2.74^{* * *}$ & $1.64^{* * *}$ & $1.79^{* * *}$ & $1.55^{* * *}$ & $2.12^{* * *}$ & $2.12^{* * *}$ & $1.61^{* *}$ & $2.67^{* * *}$ & $1.39^{*}$ \\
\hline & $(1.11-3.64)$ & $(2.09-3.60)$ & $(1.29-2.07)$ & $(1.52-2.10)$ & $(1.27-1.91)$ & $(1.61-2.78)$ & $(1.64-2.74)$ & $(1.21-2.13)$ & $(1.91-3.74)$ & $(1.07-1.80)$ \\
\hline \multirow[t]{2}{*}{$25-29$} & $2.21^{* *}$ & $2.55^{* * *}$ & $2.07^{* * *}$ & $1.97^{* * *}$ & $1.60^{* * *}$ & $2.34^{* * *}$ & $3.24^{* * *}$ & $1.64^{* *}$ & $2.74^{* * *}$ & $1.78^{* * *}$ \\
\hline & $(1.23-3.99)$ & $(1.94-3.35)$ & $(1.62-2.66)$ & $(1.67-2.32)$ & $(1.26-2.02)$ & $(1.65-3.32)$ & $(2.53-4.15)$ & $(1.21-2.23)$ & $(1.82-4.13)$ & $(1.35-2.35)$ \\
\hline \multirow[t]{2}{*}{$30-34$} & $2.44^{* *}$ & $2.98^{* * *}$ & $1.66^{* * *}$ & $2.08^{* * *}$ & $1.35^{*}$ & $2.45^{* * *}$ & $2.66^{* * *}$ & $1.84^{* * *}$ & $3.02^{* * *}$ & $1.72^{* * *}$ \\
\hline & $(1.34-4.43)$ & $(2.09-4.27)$ & $(1.27-2.16)$ & $(1.76-2.47)$ & $(1.02-1.80)$ & $(1.68-3.58)$ & $(1.96-3.63)$ & $(1.33-2.56)$ & $(2.06-4.44)$ & $(1.27-2.34)$ \\
\hline \multirow[t]{2}{*}{$35-39$} & $2.37^{* *}$ & $2.38^{* * *}$ & $1.85^{* * *}$ & $1.93^{* * *}$ & $1.42^{*}$ & $2.78^{* * *}$ & $2.33^{* * *}$ & $1.84^{* * *}$ & $2.89^{* * *}$ & $1.67^{* * *}$ \\
\hline & $(1.31-4.31)$ & $(1.68-3.37)$ & $(1.34-2.57)$ & $(1.62-2.28)$ & $(1.06-1.90)$ & $(1.90-4.08)$ & $(1.66-3.26)$ & $(1.29-2.65)$ & $(1.86-4.49)$ & $(1.24-2.27)$ \\
\hline \multirow[t]{2}{*}{$40-44$} & $2.54^{* *}$ & $1.54^{*}$ & $1.99^{* * *}$ & $2.13^{* * *}$ & $1.58^{* *}$ & $3.05^{* * *}$ & $2.53^{* * *}$ & $1.58^{*}$ & $3.19^{* * *}$ & $1.60^{* *}$ \\
\hline & $(1.38-4.68)$ & $(1.11-2.14)$ & $(1.52-2.62)$ & $(1.78-2.55)$ & $(1.18-2.12)$ & $(2.05-4.55)$ & $(1.82-3.52)$ & $(1.09-2.29)$ & $(1.96-5.20)$ & $(1.18-2.18)$ \\
\hline \multirow[t]{2}{*}{$45-49$} & $2.96^{* * *}$ & $1.97^{* * *}$ & $2.00^{* * *}$ & $2.02^{* * *}$ & $1.71^{* *}$ & $2.96^{* * *}$ & $1.54^{*}$ & $1.53^{*}$ & $4.01^{* * *}$ & $2.51 * * *$ \\
\hline & $(1.60-5.45)$ & $(1.38-2.82)$ & $(1.46-2.74)$ & $(1.66-2.46)$ & $(1.23-2.37)$ & $(1.96-4.48)$ & $(1.05-2.26)$ & $(1.06-2.23)$ & $(2.51-6.41)$ & $(1.71-3.68)$ \\
\hline \multicolumn{11}{|l|}{ Education } \\
\hline$<$ complete primary (ref) & 1.00 & 1.00 & 1.00 & 1.00 & 1.00 & 1.00 & 1.00 & wltep & 1.00 & 1.00 \\
\hline \multirow[t]{2}{*}{ Complete primary } & $1.90^{* *}$ & $1.57^{* * *}$ & 1.33 & $1.22^{* * *}$ & 0.82 & 1.21 & 1.18 & $1.43^{* *}$ & $1.47^{*}$ & 0.66 \\
\hline & $(1.21-2.96)$ & $(1.31-1.87)$ & $(0.95-1.86)$ & $(1.09-1.37)$ & $(0.58-1.15)$ & $(0.92-1.60)$ & $(0.83-1.68)$ & $(1.11-1.84)$ & $(1.10-1.97)$ & $(0.42-1.03)$ \\
\hline \multirow[t]{2}{*}{ zsome secondary } & $2.98^{* * *}$ & $3.96^{* * *}$ & $2.70^{* * *}$ & $1.62^{* * *}$ & $2.27^{* * *}$ & $2.98^{* * *}$ & $3.33^{* * *}$ & $2.39^{* * *}$ & $1.98^{* * *}$ & $1.80 * * *$ \\
\hline & $(2.36-3.76)$ & $(3.21-4.88)$ & $(2.32-3.15)$ & $(1.45-1.81)$ & $(1.81-2.84)$ & $(2.33-3.80)$ & $(2.68-4.14)$ & $(1.96-2.92)$ & $(1.50-2.61)$ & $(1.49-2.18)$ \\
\hline \multicolumn{11}{|l|}{ Wealth quintile§ } \\
\hline Poorest (ref) & 1.00 & 1.00 & 1.00 & 1.00 & 1.00 & 1.00 & 1.00 & 1.00 & 1.00 & 1.00 \\
\hline \multirow[t]{2}{*}{ Poor } & 1.07 & $1.77^{* * *}$ & 1.19 & $1.14^{*}$ & 0.78 & 1.16 & 1.26 & 1.10 & na & 0.84 \\
\hline & $(0.73-1.58)$ & $(1.33-2.34)$ & $(0.85-1.67)$ & $(1.02-1.27)$ & $(0.59-1.03)$ & $(0.90-1.50)$ & $(0.88-1.81)$ & $(0.84-1.43)$ & na & $(0.62-1.15)$ \\
\hline \multirow[t]{2}{*}{ Middle } & $1.67^{* *}$ & $2.00^{* * *}$ & $1.77^{* *}$ & $1.19^{* *}$ & 0.93 & 1.06 & $1.49^{*}$ & 1.10 & 1.39 & 1.01 \\
\hline & $(1.19-2.36)$ & $(1.47-2.73)$ & $(1.24-2.53)$ & $(1.05-1.34)$ & $(0.69-1.27)$ & $(0.81-1.40)$ & $(1.05-2.11)$ & $(0.81-1.50)$ & (0.98-1.99) & $(0.71-1.45)$ \\
\hline \multirow[t]{2}{*}{ Rich } & $2.16^{* * *}$ & $2.46^{* * *}$ & $2.57^{* * *}$ & $1.28^{* * *}$ & $1.50^{*}$ & 1.10 & $2.20^{* * *}$ & 1.15 & $2.52^{* * *}$ & 1.43 \\
\hline & $(1.51-3.08)$ & $(1.82-3.33)$ & $(1.79-3.69)$ & $(1.12-1.47)$ & $(1.08-2.10)$ & $(0.83-1.46)$ & $(1.55-3.13)$ & $(0.85-1.55)$ & $(1.64-3.89)$ & $(0.96-2.12)$ \\
\hline \multirow[t]{2}{*}{ Richest } & $3.28^{* * *}$ & $4.06^{* * *}$ & $4.69^{* * *}$ & $1.50^{* * *}$ & $3.62^{* * *}$ & $1.89^{* * *}$ & $4.38^{* * *}$ & $1.87^{* * *}$ & $3.52^{* * *}$ & $1.90^{* *}$ \\
\hline & $(2.28-4.71)$ & $(2.77-5.94)$ & $(3.19-6.90)$ & $(1.27-1.77)$ & $(2.51-5.23)$ & $(1.41-2.53)$ & $(3.09-6.23)$ & $(1.36-2.59)$ & $(2.20-5.63)$ & $(1.17-3.09)$ \\
\hline \multicolumn{11}{|l|}{ Location } \\
\hline Rural (ref) & 1.00 & 1.00 & 1.00 & 1.00 & 1.00 & 1.00 & 1.00 & 1.00 & 1.00 & 1.00 \\
\hline \multirow[t]{2}{*}{ Urban } & 1.51 & 0.98 & $1.32^{*}$ & 0.85 & 0.82 & 1.21 & 1.21 & 1.22 & 1.06 & 0.77 \\
\hline & $(0.58-3.90)$ & $(0.69-1.40)$ & $(1.04-1.67)$ & $(0.72-1.01)$ & $(0.65-1.03)$ & $(0.92-1.60)$ & $(0.94-1.56)$ & $(0.88-1.71)$ & $(0.77-1.44)$ & $(0.50-1.18)$ \\
\hline \multicolumn{11}{|l|}{ F-statistic for regional } \\
\hline indicators & 1.16 & 20.34 & 12.30 & 4.87 & 9.36 & 13.15 & 1.68 & 2.43 & 10.03 & 6.37 \\
\hline$N$ & 16,507 & 8,424 & 17,346 & 22,929 & 9,738 & 11,294 & 4,960 & 8,510 & 7,138 & 8,872 \\
\hline
\end{tabular}



WEB APPENDIX TABLE 2. Odds ratios (and 95\% confidence intervals) from logistic regression analyses identifying associations between women's characteristics and having heard of emergency contraception, West
and Central Africa

\begin{tabular}{|c|c|c|c|c|c|c|c|c|c|c|c|c|c|c|}
\hline $\begin{array}{l}\text { and Central Africa } \\
\text { Characteristic }\end{array}$ & Benin & Burkina Faso & Cameroon & Chad & DRC & Ghana & Guinea & Liberia & Mali & Niger & Nigeria & $\begin{array}{l}\text { Sao Tome } \\
\text { and Principe }\end{array}$ & Senegal & Sierra Leone \\
\hline \multicolumn{15}{|l|}{ Marital statust } \\
\hline Currently married (ref) & 1.00 & 1.00 & 1.00 & 1.00 & 1.00 & 1.00 & 1.00 & 1.00 & 1.00 & 1.00 & 1.00 & 1.00 & 1.00 & 1.00 \\
\hline Never married & 1.03 & 0.99 & 0.85 & 1.05 & 0.80 & 1.08 & 1.23 & $0.67^{* *}$ & $0.46^{* * *}$ & 0.79 & 1.01 & 0.96 & $0.71^{* *}$ & 1.17 \\
\hline & $(0.84-1.25)$ & $(0.71-1.39)$ & $(0.69-1.04)$ & $(0.58-1.90)$ & $(0.63-1.03)$ & $(0.86-1.35)$ & $(0.81-1.88)$ & $(0.50-0.90)$ & $(0.32-0.67)$ & (0.55-1.15) & $(0.88-1.15)$ & $(0.61-1.50)$ & $(0.55-0.91)$ & $(0.85-1.60)$ \\
\hline Formerly married & $1.35^{*}$ & 0.83 & $\begin{array}{l}1.12 \\
(0.91-138)\end{array}$ & $\begin{array}{l}1.28 \\
(077-214)\end{array}$ & 1.06 & 1.13 & $\begin{array}{l}1.32 \\
(074-236)\end{array}$ & $1.90^{* * *}$ & 1.10 & 1.08 & 1.10 & na & 0.87 & 1.46 \\
\hline \multicolumn{15}{|c|}{)$\quad(0 . / 3-1.00) \quad(0.50-1.53)$} \\
\hline \multirow{3}{*}{$\begin{array}{l}15-19 \text { (ref) } \\
20-24\end{array}$} & 1.00 & 1.00 & 1.00 & 1.00 & 1.00 & 1.00 & 1.00 & 1.00 & 1.00 & 1.00 & 1.00 & 1.00 & 1.00 & 1.00 \\
\hline & $2.12^{* * *}$ & $2.16^{* * *}$ & $1.94^{* * *}$ & 1.68 & $1.63^{* *}$ & $2.08^{* * *}$ & $1.89^{* *}$ & 1.06 & $1.32^{*}$ & 1.29 & $2.33^{* * *}$ & $2.19^{* *}$ & $1.77^{* * *}$ & $1.99 * * *$ \\
\hline & $(1.68-2.68)$ & $(1.51-3.09)$ & $(1.59-2.36)$ & $(0.78-3.62)$ & $(1.20-2.22)$ & $(1.64-2.64)$ & $(1.21-2.94)$ & $(0.72-1.55)$ & $(1.05-1.68)$ & $(0.89-1.87)$ & $(2.00-2.71)$ & $(1.35-3.57)$ & $(1.26-2.40)$ & $(1.34-2.97)$ \\
\hline \multirow[t]{2}{*}{$25-29$} & $2.80^{* * *}$ & $2.10^{* * *}$ & $2.33^{* * *}$ & $3.88^{* * 0}$ & $2.22^{* * *}$ & $2.03^{* * *}$ & $2.58^{* * * * 11}$ & 1.29 & $1.46^{* *}$ & $2.00 *$ & $2.90^{* * *}$ & $1.91^{*}$ & $2.22^{* * * * * 1}$ & $2.01^{* *}$ \\
\hline & $(2.17-3.62)$ & $(1.44-3.06)$ & $(191-297)$ & $(198-760)$ & $(1.47-3,29)$ & $(1.52-272)$ & $(1.48-4.51)$ & $(0,79-2,10)$ & $(1.10-1.95)$ & $(1.28-3.12)$ & $(244-3.46)$ & $(105-3.45)$ & $(1.56-3.30)$ & $(1,31-3,11)$ \\
\hline \multirow{2}{*}{ 30-34 } & $2.94^{* * *}$ & $2.38^{* * * *}$ & 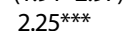 & 2.25 & $1.93 * * * 3$ & $2.06^{* * * *}$ & $2.15 * *$ & 1.16 & 1.26 & $2.04 * * 1$ & $3.39 * * *$ & $2.57^{*}$ & $2.37 * * * 3$ & $2.26^{* * *}$ \\
\hline & $(2.25-3.83)$ & $(1.63-3.50)$ & $(1.76-2.88)$ & $(0.84-6.02)$ & $(1.42-2.63)$ & $(1.52-2.79)$ & $(1.26-3.67)$ & $(0.74-1.84)$ & $(0.94-1.69)$ & $(1.30-3.20)$ & $(2.80-4.12)$ & $(1.23-5.36)$ & $(1.65-3.41)$ & $(1.44-3.55)$ \\
\hline \multirow{2}{*}{$35-39$} & $2.54^{* * *}$ & $2.30^{* * *}$ & $1.99 * * *$ & $4.88^{* * *}$ & $1.86^{* *}$ & $1.71^{* *}$ & $1.81^{*}$ & 1.01 & $1.39^{*}$ & 1.39 & $3.04^{* * *}$ & $2.08^{*}$ & $2.14^{* * * * 11}$ & $1.73^{*}$ \\
\hline & $(1.92-3.35)$ & $(1.54-3.45)$ & $(1.52-2.60)$ & $(2.06-11.57)$ & $(1.26-2.73)$ & $(1.24-2.35)$ & $(1.03-3.17)$ & $(0.62-1.66)$ & $(1.08-1.79)$ & $(0.85-2.28)$ & $(2.51-3.68)$ & $(1.09-3.99)$ & $(1.48-3.10)$ & $(1.02-2.93)$ \\
\hline \multirow[t]{2}{*}{$40-44$} & $2.66^{* * *}$ & $1.98^{* *}$ & $1.85^{* * *}$ & $4.06^{*}$ & $2.34^{* * *}$ & 1.39 & $3.16^{* * *}$ & 0.80 & 1.30 & 1.55 & $3.30 * * * 010$ & $2.46^{* *}$ & $2.15^{* * *}$ & $2.61^{* * * 3}$ \\
\hline & $(2.02-3.51)$ & $(1.27-3.07)$ & $(1.38-2.47)$ & $(1.35-12.21)$ & $(1.57-3.51)$ & $(0.95-2.05)$ & $(1.86-5.39)$ & $(0.50-1.28)$ & $(0.94-1.79)$ & $(0.95-2.55)$ & $(2.68-4.08)$ & $(1.27-4.78)$ & $(1.45-3.21)$ & $(1.53-4.47)$ \\
\hline \multirow[t]{2}{*}{$45-49$} & $3.35^{* * *}$ & $2.06^{* * *}$ & $1.57^{* *}$ & $5.44^{*}$ & $1.84^{* *}$ & $1.58^{* *}$ & $2.51^{* * *}$ & 0.71 & $1.51^{*}$ & 1.13 & $2.47^{* * *}$ & $2.13^{*}$ & $2.38^{* * * 211}$ & 1.12 \\
\hline & $(2.47-4.54)$ & $(1.38-3.07)$ & $(1.12-2.20)$ & $(1.74-17.07)$ & $(1.22-2.78)$ & $(1.12-2.24)$ & $(1.48-4.27)$ & $(0.41-1.23)$ & $(1.10-2.06)$ & $(0.62-2.09)$ & $(1.96-3.11)$ & $(1.13-4.02)$ & $(1.61-3.53)$ & $(0.58-2.18)$ \\
\hline $\begin{array}{l}\text { Education₹ } \\
\text { <omplete primary (ref) }\end{array}$ & 100 & 100 & 100 & 100 & 100 & 100 & 100 & & & & & & & \\
\hline \multirow{2}{*}{$\begin{array}{l}\text { <complete primary (ref) } \\
\text { Complete primary }\end{array}$} & 1.23 & $1.88^{* * *}$ & $2.00^{* * *}$ & $6.42^{* * * *}$ & $1.89^{* * * *}$ & $\begin{array}{l}1.00 \\
1.50^{*}\end{array}$ & $\begin{array}{l}1.90 \\
2.94^{*}\end{array}$ & $1.77^{* *}$ & $\begin{array}{l}1.00 \\
1.48\end{array}$ & $\begin{array}{l}1.00 \\
1.61\end{array}$ & $\begin{array}{l}1.00 \\
2.01 * *\end{array}$ & $\begin{array}{r}1.00 \\
\text { na }\end{array}$ & $\begin{array}{l}1.00 \\
0.72\end{array}$ & $\begin{array}{l}1.00 \\
2.30^{* *}\end{array}$ \\
\hline & $(0.87-1.74)$ & $(1.30-2.74)$ & $(1.60-2.52)$ & $(2.45-16.85)$ & $(1.33-2.69)$ & $(1.09-2.08)$ & $(1.30-6.66)$ & $(1.21-2.61)$ & $(0.83-2.63)$ & $(0.93-2.77)$ & $(1.69-2.40)$ & na & $(0.38-1.35)$ & $(1.31-4.04)$ \\
\hline \multirow{2}{*}{ zsome secondary } & $2.91^{* * *}$ & $4.40^{* * * *}>2>>20$ &  & $10.38^{* * *}$ & 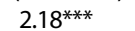 & $1.58^{* * *}$ & $2.95^{* * *}>0>0$ & 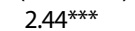 &  & $2.44^{* * *}$ & $3.55^{* * *}>2>-10$ &  & $3.03 * * *$ & $3.37^{* * *}$ \\
\hline \multirow{2}{*}{\multicolumn{15}{|c|}{ Wealth quintile§ }} \\
\hline & & & & & & & & & & & & & & \\
\hline \multirow[b]{2}{*}{$\begin{array}{l}\text { Poorest (ref } \\
\text { Poor }\end{array}$} & 1.00 & 1.00 & 1.00 & 1.00 & 1.00 & 1.00 & 1.00 & 1.00 & 1.00 & 1.00 & 1.00 & 1.00 & 1.00 & 1.00 \\
\hline & 1.05 & $1.69 * *$ & $1.39^{*}$ & na & 1.42 & $1.46^{*}$ & 1.27 & 1.28 & 0.97 & 0.64 & 1.23 & 0.68 & $1.52 *$ & 1.24 \\
\hline \multirow{2}{*}{ Middle } & $\begin{array}{l}(0.81-1.3 /) \\
1.21\end{array}$ & $\begin{array}{l}(1.22-2.36) \\
1.45\end{array}$ & $\begin{array}{l}(1.02-1.8 /) \\
2.08 * * *\end{array}$ & $\begin{array}{c}\text { na } \\
10.13^{*}\end{array}$ & $\begin{array}{l}(0.94-2.17) \\
1.21\end{array}$ & $\begin{array}{l}(1.07-1.98) \\
1.97^{* * *}\end{array}$ & $\begin{array}{l}(0.59-2.71) \\
2.56^{*}\end{array}$ & $\begin{array}{l}(0.65-2.55) \\
1.66\end{array}$ & $\begin{array}{l}(0.74-1.28) \\
0.77\end{array}$ & $\begin{array}{l}(0.31-1.35) \\
0.66\end{array}$ & $\begin{array}{l}(0.94-1.61) \\
1.69 * * *\end{array}$ & $\begin{array}{l}(0.43-1.06) \\
1.16\end{array}$ & $\begin{array}{l}(1.11-2.08) \\
1.38\end{array}$ & $\begin{array}{l}(0.70-2.17) \\
1.21\end{array}$ \\
\hline & $(0.90-1.62)$ & $(0.97-2.16)$ & $(1.53-2.83)$ & $(1.59-64.63)$ & $(0.74-1.97)$ & $(1.40-2.77)$ & $(1.22-5.37)$ & $(0.85-3.24)$ & $(0.55-1.08)$ & $(0.35-1.24)$ & $(1.26-2.28)$ & $(0.79-1.70)$ & $(0.95-2.00)$ & $(0.58-2.51)$ \\
\hline \multirow[t]{2}{*}{ Rich } & $1.50^{* *}$ & $1.64^{* *}$ & $1.96 * * *$ & $11.14^{*}$ & $2.19^{* * *}$ & $2.26^{* * *}$ & $3.28^{* *}$ & $2.10^{*}$ & 1.02 & 0.74 & $2.22 * * *$ & & $2.01 * * *$ & \\
\hline & $(1.11-2.04)$ & $(1.16-2.33)$ & $(1.40-2.77)$ & $(1.41-88.18)$ & $(1.41-3.41)$ & $(1.58-3.24)$ & $(1.62-6.62)$ & $(1.07-4.11)$ & $(0.75-1.40)$ & $(0.37-1.46)$ & $(1.65-3.00)$ & $(0.73-1.62)$ & $(1.35-3.01)$ & $(0.97-3.79)$ \\
\hline \multirow[t]{2}{*}{ Richest } & $2.44^{* * *}$ & $2.52^{* * *}$ & $2.88^{* * *}$ & $58.16^{* * *}$ & $2.90^{* * *}$ & $3.20^{* * *}$ & $7.75^{* * *}$ & & & & $3.12^{2 * * *}$ & $1.66^{*}$ & $1.56^{*}$ & $2.71^{* *}$ \\
\hline & $(1.78-3.35)$ & $(1.54-4.14)$ & $(2.01-4.14)$ & $(10.11-334.78)$ & $(1.73-4.87)$ & $(2.13-4.79)$ & $(2.48-24.22)$ & $(0.95-3.98)$ & $(0.97-2.24)$ & $(0.75-2.51)$ & $(2.29-4.26)$ & $(1.09-2.51)$ & $(1.02-2.37)$ & $(1.30-5.61)$ \\
\hline $\begin{array}{l}\text { Location } \\
\text { Rural (ref) }\end{array}$ & 100 & 100 & 100 & 100 & 100 & 100 & 100 & 100 & 100 & $100>2-2>0$ & 100 & 100 & 100 & 100 \\
\hline \multirow[t]{2}{*}{ Urban } & 1.20 & $\begin{array}{l}1.00 \\
1.34\end{array}$ & 1.13 & $0.25 *$ & $1.56^{*}$ & $\begin{array}{l}1.00 \\
1.04\end{array}$ & 0.54 & $\begin{array}{l}1.00 \\
1.31 \\
072.271\end{array}$ & 1.06 & $\begin{array}{l}1.00 * * \\
3.37 * *\end{array}$ & $\begin{array}{l}1.00 \\
1.11\end{array}$ & $\begin{array}{l}1.00 \\
0.75\end{array}$ & $\begin{array}{l}1.00 \\
1.16\end{array}$ & $\begin{array}{l}1.00 \\
1.12 \\
061.06\end{array}$ \\
\hline & $(0.98-1.47)$ & $(0.83-2.16)$ & $(0.90-1.42)$ & $(0.11-0.57)$ & $(1.02-2.41)$ & $(0.81-1.34)$ & $(0.24-1.21)$ & $(0.73-2.37)$ & $(0.75-1.49)$ & $(1.95-5.83)$ & $(0.94-1.31)$ & $(0.53-1.07)$ & $(0.82-1.65)$ & $(0.64-1.96)$ \\
\hline \multirow{2}{*}{$\begin{array}{l}\text { F-statisticfor regional } \\
\text { indicators }\end{array}$} & 12.53 & 5.13 & 50.51 & 7.92 & 3.19 & 6.01 & 6.44 & 2.04 & 21.42 & 7.60 & 41.90 & 7.67 & 2.74 & 21.29 \\
\hline & 17,664 & 12,466 & 10,604 & 6,083 & 9,958 & 4,876 & 7,917 & 7,045 & 14,518 & 9,195 & 33,141 & 2,613 & 14,546 & 7,358 \\
\hline
\end{tabular}




\begin{tabular}{|c|c|c|c|c|c|c|c|}
\hline Characteristic & Kenya & Madagascar & Malawi & Namibia & Swaziland & Zambia & Zimbabwe \\
\hline \multicolumn{8}{|l|}{ Marital status } \\
\hline Currently married (ref) & 1.00 & 1.00 & 1.00 & 1.00 & 1.00 & 1.00 & 1.00 \\
\hline Never married & $\begin{array}{l}2.69^{* * *} \\
(1.66-4.35)\end{array}$ & $\begin{array}{l}0.42 \\
(0.12-1.46)\end{array}$ & $\begin{array}{l}0.72 \\
(0.24-2.15)\end{array}$ & $\begin{array}{l}1.11 \\
(0.69-1.81)\end{array}$ & $\begin{array}{l}1.45 \\
(0.95-2.23)\end{array}$ & $\begin{array}{l}1.57 \\
(0.34-7.32)\end{array}$ & $\begin{array}{l}0.75 \\
(0.34-1.67)\end{array}$ \\
\hline Formerly married & $\begin{array}{l}2.11^{*} \\
(1.07-4.13)\end{array}$ & $\begin{array}{l}1.25 \\
(0.66-2.40)\end{array}$ & $\begin{array}{l}1.46 \\
(0.86-2.48)\end{array}$ & $\begin{array}{l}1.88 \\
(0.81-4.36)\end{array}$ & $\begin{array}{l}0.88 \\
(0.39-2.01)\end{array}$ & $\begin{array}{l}2.22^{*} \\
(1.01-4.88)\end{array}$ & $\begin{array}{l}0.52^{*} \\
(0.29-0.92)\end{array}$ \\
\hline \multicolumn{8}{|l|}{ Age } \\
\hline $15-19$ (ref) & 1.00 & 1.00 & 1.00 & 1.00 & 1.00 & 1.00 & 1.00 \\
\hline $20-24$ & $\begin{array}{l}2.36 \\
(0.96-5.81)\end{array}$ & $\begin{array}{l}1.22 \\
(0.47-3.15)\end{array}$ & $\begin{array}{l}1.32 \\
(0.47-3.72)\end{array}$ & $\begin{array}{l}1.54 \\
(0.68-3.52)\end{array}$ & $\begin{array}{l}4.85^{* *} \\
(1.65-14.27)\end{array}$ & $\begin{array}{l}1.08 \\
(0.55-2.12)\end{array}$ & $\begin{array}{l}2.11 \\
(0.72-6.15)\end{array}$ \\
\hline $25-29$ & $\begin{array}{l}2.10 \\
(0.88-5.03)\end{array}$ & $\begin{array}{l}1.84 \\
(0.66-5.17)\end{array}$ & $\begin{array}{l}2.00 \\
(0.73-5.51)\end{array}$ & $\begin{array}{l}1.40 \\
(0.63-3.10)\end{array}$ & $\begin{array}{l}7.83^{* * * *} \\
(2.68-22.94)\end{array}$ & $\begin{array}{l}1.37 \\
(0.39-4.75)\end{array}$ & $\begin{array}{l}3.67^{* *} \\
(1.43-9.43)\end{array}$ \\
\hline $30-34$ & $\begin{array}{l}1.06 \\
(0.39-2.85)\end{array}$ & $\begin{array}{l}2.15 \\
(0.80-5.76)\end{array}$ & $\begin{array}{l}2.54 \\
(0.93-6.94)\end{array}$ & $\begin{array}{l}1.02 \\
(0.40-2.65)\end{array}$ & $\begin{array}{l}6.82^{* *} \\
(2.09-22.29)\end{array}$ & $\begin{array}{l}1.08 \\
(0.27-4.33)\end{array}$ & $\begin{array}{l}2.42 \\
(0.82-7.09)\end{array}$ \\
\hline $35-39$ & $\begin{array}{l}0.87 \\
(0.29-2.58)\end{array}$ & $\begin{array}{l}0.74 \\
(0.25-2.20)\end{array}$ & $\begin{array}{l}1.10 \\
(0.36-3.35)\end{array}$ & $\begin{array}{l}1.15 \\
(0.40-3.27)\end{array}$ & $\begin{array}{l}5.53^{* *} \\
(1.65-18.50)\end{array}$ & $\begin{array}{l}1.08 \\
(0.27-4.45)\end{array}$ & $\begin{array}{l}2.40 \\
(0.76-7.62)\end{array}$ \\
\hline $40-44$ & $\begin{array}{l}0.57 \\
(0.17-1.88)\end{array}$ & $\begin{array}{l}1.32 \\
(0.40-4.32)\end{array}$ & $\begin{array}{l}0.96 \\
(0.29-3.20)\end{array}$ & $\begin{array}{l}1.27 \\
(0.47-3.43)\end{array}$ & $\begin{array}{l}2.48 \\
(0.60-10.33)\end{array}$ & $\begin{array}{l}1.36 \\
(0.29-6.52)\end{array}$ & $\begin{array}{l}2.38 \\
(0.38-15.12)\end{array}$ \\
\hline $45-49$ & $\begin{array}{l}0.70 \\
(0.25-1.94)\end{array}$ & $\begin{array}{l}0.76 \\
(0.23-2.53)\end{array}$ & $\begin{array}{l}1.88 \\
(0.62-5.72)\end{array}$ & $\begin{array}{l}0.47 \\
(0.13-1.66)\end{array}$ & $\begin{array}{l}1.08 \\
(0.18-6.38)\end{array}$ & $\begin{array}{l}2.65^{*} \\
(1.10-6.38)\end{array}$ & $\begin{array}{l}3.61^{*} \\
(1.13-11.50)\end{array}$ \\
\hline \multicolumn{8}{|l|}{ Education } \\
\hline$<$ complete primary (ref) & 1.00 & 1.00 & 1.00 & 1.00 & 1.00 & 1.00 & 1.00 \\
\hline Complete primary & $\begin{array}{l}0.96 \\
(0.41-2.23)\end{array}$ & $\begin{array}{l}0.11^{*} \\
(0.01-0.86)\end{array}$ & $\begin{array}{l}1.06 \\
(0.48-2.35)\end{array}$ & $\begin{array}{l}1.64 \\
(0.54-4.95)\end{array}$ & $\begin{array}{l}1.27 \\
(0.32-5.01)\end{array}$ & $\begin{array}{l}3.18^{*} \\
(1.06-9.57)\end{array}$ & $\begin{array}{l}1.08 \\
(0.41-2.81)\end{array}$ \\
\hline$\geq$ some secondary & $\begin{array}{l}2.88^{* *} \\
(1.31-6.36)\end{array}$ & $\begin{array}{l}2.08^{*} \\
(1.01-4.31)\end{array}$ & $\begin{array}{l}1.78^{*} \\
(1.04-3.05)\end{array}$ & $\begin{array}{l}1.64 \\
(0.90-3.00)\end{array}$ & $\begin{array}{l}5.67^{* * *} \\
(2.21-14.59)\end{array}$ & $\begin{array}{l}1.46 \\
(0.32-6.67)\end{array}$ & $\begin{array}{l}0.94 \\
(0.60-1.45)\end{array}$ \\
\hline \multicolumn{8}{|l|}{ Wealth quintilet } \\
\hline Poorest (ref) & 1.00 & 1.00 & 1.00 & 1.00 & 1.00 & 1.00 & 1.00 \\
\hline Poor & $\begin{array}{l}1.09 \\
(0.16-7.39)\end{array}$ & $\begin{array}{l}1.42 \\
(0.13-15.45)\end{array}$ & $\begin{array}{l}0.98 \\
(0.48-2.00)\end{array}$ & $\begin{array}{l}0.80 \\
(0.28-2.26)\end{array}$ & $\begin{array}{l}0.73 \\
(0.24-2.23)\end{array}$ & $\begin{array}{l}\text { na } \\
\text { na }\end{array}$ & $\begin{array}{l}0.69 \\
(0.21-2.31)\end{array}$ \\
\hline Middle & $\begin{array}{l}3.07 \\
(0.51-18.29)\end{array}$ & $\begin{array}{l}5.82 \\
(0.94-36.02)\end{array}$ & $\begin{array}{l}1.12 \\
(0.54-2.33)\end{array}$ & $\begin{array}{l}1.00 \\
(0.37-2.70)\end{array}$ & $\begin{array}{l}1.00 \\
(0.37-2.70)\end{array}$ & $\begin{array}{l}3.74 \\
(0.68-20.53)\end{array}$ & $\begin{array}{l}1.20 \\
(0.35-4.15)\end{array}$ \\
\hline Rich & $\begin{array}{l}2.60 \\
(0.49-13.86)\end{array}$ & $\begin{array}{l}9.44^{*} \\
(1.70-52.48)\end{array}$ & $\begin{array}{l}1.53 \\
(0.80-2.94)\end{array}$ & $\begin{array}{l}1.69 \\
(0.62-4.58)\end{array}$ & $\begin{array}{l}1.43 \\
(0.59-3.47)\end{array}$ & $\begin{array}{l}5.32 \\
(0.69-40.90)\end{array}$ & $\begin{array}{l}1.17 \\
(0.29-4.74)\end{array}$ \\
\hline Richest & $\begin{array}{l}9.21^{* *} \\
(1.72-49.39)\end{array}$ & $\begin{array}{l}9.28^{*} \\
(1.57-54.84)\end{array}$ & $\begin{array}{l}1.57 \\
(0.77-3.19)\end{array}$ & $\begin{array}{l}2.10 \\
(0.72-6.18)\end{array}$ & $\begin{array}{l}3.21^{* *} \\
(1.33-7.76)\end{array}$ & $\begin{array}{l}8.13^{*} \\
(1.14-57.79)\end{array}$ & $\begin{array}{l}0.94 \\
(0.18-4.81)\end{array}$ \\
\hline \multicolumn{8}{|l|}{ Location } \\
\hline Rural (ref) & 1.00 & 1.00 & 1.00 & 1.00 & 1.00 & 1.00 & 1.00 \\
\hline Urban & $\begin{array}{l}0.71 \\
(0.34-1.49)\end{array}$ & $\begin{array}{l}2.75^{* * *} \\
(1.53-4.93)\end{array}$ & $\begin{array}{l}0.91 \\
(0.49-1.69)\end{array}$ & $\begin{array}{l}0.91 \\
(0.53-1.56)\end{array}$ & $\begin{array}{l}0.93 \\
(0.54-1.60)\end{array}$ & $\begin{array}{l}1.60 \\
(0.55-4.66)\end{array}$ & $\begin{array}{l}1.34 \\
(0.42-4.22)\end{array}$ \\
\hline $\begin{array}{l}\text { F-statistic for regional } \\
\text { indicators }\end{array}$ & 4.32 & 1.78 & 2.30 & 5.10 & 2.59 & 1.85 & 3.34 \\
\hline$N$ & 6,479 & 14,930 & 18,607 & 7,482 & 3,740 & 5,744 & 6,708 \\
\hline
\end{tabular}




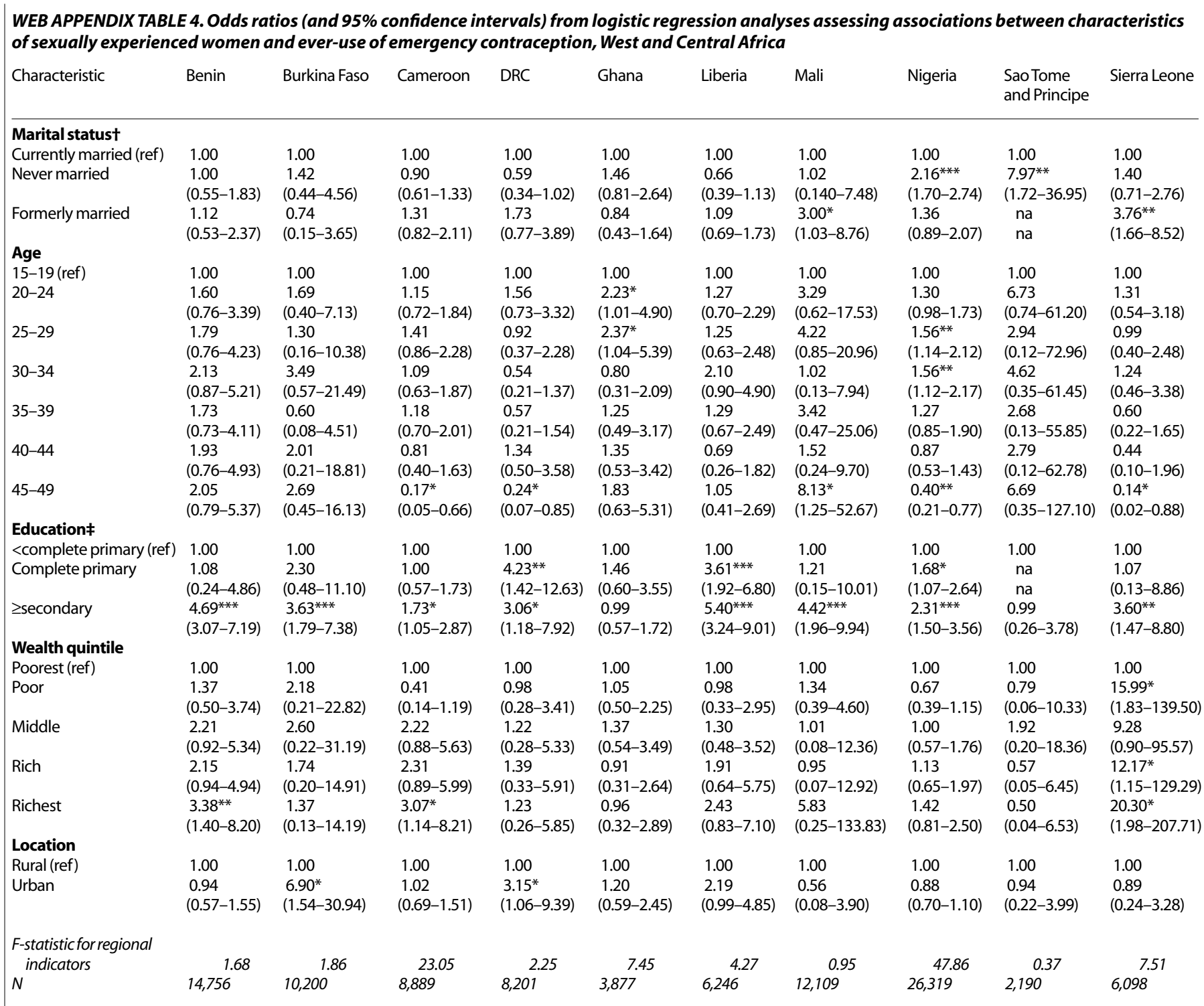

${ }^{*} \mathrm{p}<.05 .{ }^{* *} \mathrm{p}<.01 .{ }^{* * *} \mathrm{p}<.001$. + For Sao Tome and Principe, the reference category includes formerly married women. $\neq$ For Sao Tome and Principe, the reference category includes those who have completed primary school. Notes: All models control for region within country. Regression was not run on data from Chad, Guinea, Niger and Senegal because of low rates of emergency contraception use. DRC=Democratic Republic of Congo. na=not applicable. 
WEB APPENDIX TABLE 5. Odds ratios (and 95\% confidence intervals) from logistic regression analyses assessing associations between women's characteristics and having heard of or having ever used emergency contraception, Asia

\begin{tabular}{|c|c|c|c|c|c|c|c|c|c|c|c|c|c|}
\hline \multirow[b]{2}{*}{ Characteristic } & \multirow{2}{*}{$\begin{array}{l}\text { Cambodiat } \\
\text { Heard of }\end{array}$} & \multicolumn{2}{|l|}{ India } & \multicolumn{2}{|l|}{ Indonesiał } & \multicolumn{2}{|l|}{ Maldivesł } & \multirow{2}{*}{$\begin{array}{l}\text { Nepalt } \\
\text { Heard of }\end{array}$} & \multicolumn{2}{|l|}{ Pakistan‡ } & \multicolumn{2}{|l|}{ Philippines } & \multirow{2}{*}{$\begin{array}{l}\text { Timor- } \\
\text { Leste† }\end{array}$} \\
\hline & & Heard of & Used & Heard of & Used & Heard of & Used & & Heard of & Used & Heard of & Used & \\
\hline \multicolumn{14}{|l|}{ Marital status } \\
\hline Current & 1.00 & 1.00 & 1.00 & 1.00 & 1.00 & 1.00 & 1.00 & 1.00 & 1.00 & 1.00 & 1.00 & 1.00 & 1.00 \\
\hline Never married & & $0.50^{* * *}$ & 3.09 & na & na & na & na & $0.01^{* * *}$ & na & na & $1.41^{* * *}$ & 1.07 & $0.62^{*}$ \\
\hline & $(0.57-1.06)$ & $(0.46-0.56)$ & $(0.51-18.89)$ & na & na & na & na & $(0.00-0.03)$ & na & na & $(1.17-1.70)$ & $(0.27-4.28)$ & $(0.43-0.90)$ \\
\hline Formerly married & 1.16 & 0.95 & 0.97 & 0.93 & 0.56 & 1.10 & 2.18 & 1.01 & $0.71^{*}$ & 0.77 & 0.99 & 1.07 & 0.63 \\
\hline & $(0.81-1.67)$ & $(0.83-1.08)$ & $(0.31-3.10)$ & $(0.70-1.25)$ & $(0.11-2.84)$ & $(0.86-1.41)$ & $(0.63-7.55)$ & $(0.58-1.77)$ & $(0.51-1.00)$ & $(0.24-2.52)$ & $(0.73-1.34)$ & $(0.25-4.55)$ & $(0.32-1.23)$ \\
\hline \multirow{3}{*}{$\begin{array}{l}15-19 \text { (ref) } \\
20-24\end{array}$} & 1.00 & 1.00 & 1.00 & 1.00 & 1.00 & 1.00 & 1.00 & 1.00 & 1.00 & 1.00 & 1.00 & 1.00 & 1.00 \\
\hline & 1.32 & $1.43^{* * *}$ & 2.44 & na & na & na & na & 1.23 & 1.35 & 1.66 & $1.41^{* *}$ & $0.14^{*}$ & $1.74^{*}$ \\
\hline & $(0.96-1.82)$ & $(1.29-1.59)$ & $(0.64-9.23)$ & na & na & na & na & $(0.79-1.91)$ & $(0.88-2.05)$ & $(0.29-9.57)$ & $(1.12-1.77)$ & $(0.02-0.75)$ & $(1.07-2.81)$ \\
\hline \multirow{2}{*}{$25-29$} & $1.64^{* *}$ & $1.68^{* * *}$ & $5.99^{* *}$ & $1.28^{*}$ & 1.71 & 1.17 & 2.46 & 1.50 & $2.14^{* * * *}$ & 2.95 & $1.46^{* *}$ & 0.36 & $1.89^{*}$ \\
\hline & $(1.13-2.36)$ & $(1.49-1.88)$ & $(1.69-20.98)$ & $(1.01-1.63)$ & $(0.28-10.61)$ & $(0.95-1.44)$ & $(0.70-8.74)$ & $(0.99-2.28)$ & $(1.44-3.18)$ & $(0.56-15.64)$ & $(1.14-1.87)$ & $(0.11-1.21)$ & $(1.10-3.24)$ \\
\hline \multirow{2}{*}{$30-34$} & $2.21^{* * *}$ & $1.74^{* * *}$ & $5.88^{* *}$ & $1.32^{*}$ & 2.45 & 1.19 & 3.02 & 1.47 & $2.13^{* * *}$ & 3.57 & $1.45^{*}$ & 0.42 & $2.55^{* *}$ \\
\hline & $(1.51-3.23)$ & $(1.53-1.97)$ & $(1.64-20.94)$ & $(1.04-1.68)$ & $(0.46-12.96)$ & $(0.95-1.48)$ & $(0.89-10.20)$ & $(0.94-2.30)$ & $(1.43-3.17)$ & $(0.72-17.82)$ & $(1.09-1.94)$ & $(0.13-1.35)$ & $(1.45-4.47)$ \\
\hline \multirow{2}{*}{ 35-39 } & $1.88^{* *}$ & $1.77^{* * *}$ & $5.96 * *$ & 1.07 & 1.43 & 1.10 & 2.43 & 1.31 & $2.26^{* * *}$ & 2.69 & 1.31 & $0.19^{*}$ & $2.48^{* *}$ \\
\hline & $(1.24-2.85)$ & $(1.56-2.01)$ & $(1.68-21.11)$ & $(0.84-1.36)$ & $(0.29-7.22)$ & $(0.87-1.39)$ & $(0.58-10.20)$ & $(0.84-2.05)$ & $(1.51-3.38)$ & $(0.52-13.97)$ & $(0.99-1.72)$ & $(0.05-0.77)$ & $(1.39-4.44)$ \\
\hline \multirow[t]{2}{*}{$40-44$} & $2.11^{* * *}$ & $1.54^{* * *}$ & 1.98 & $1.37^{*}$ & 3.92 & 1.12 & 0.96 & 0.92 & $2.39 * * * 1$ & 1.75 & $1.56 * *$ & 0.26 & $3.20^{* * *}$ \\
\hline & $(1.41-3.14)$ & $(1.35-1.76)$ & $(0.51-7.69)$ & $(1.05-1.79)$ & $(0.69-22.29)$ & $(0.84-1.49)$ & $(0.17-5.54)$ & $(0.51-1.63)$ & $(1.59-3.60)$ & $(0.31-10.01)$ & $(1.17-2.08)$ & $(0.06-1.03)$ & $(1.80-5.67)$ \\
\hline \multirow{2}{*}{$45-49$} & $2.17^{* * *}$ & $1.35^{* * *}$ & 2.20 & 1.25 & 1.78 & $1.44^{*}$ & 0.24 & 0.91 & $2.29 * * * 1$ & 2.96 & $1.51 * *$ & $0.24^{*}$ & $2.52^{* *}$ \\
\hline & $(1.41-3.33)$ & $(1.17-1.56)$ & $(0.54-8.91)$ & $(0.92-1.70)$ & $(0.22-14.09)$ & $(1.07-1.93)$ & $(0.02-2.60)$ & $(0.50-1.66)$ & $(1.50-3.50)$ & $(0.56-15.53)$ & $(1.12-2.02)$ & $(0.06-0.95)$ & $(1.29-4.90)$ \\
\hline \multirow{2}{*}{$\begin{array}{l}\text { Education } \\
\text { <complete primary (ref) } \\
\text { Complete primary }\end{array}$} & 1.00 & 1.00 & 1.00 & 1.00 & 1.00 & 1.00 & 1.00 & 1.00 & 1.00 & 1.00 & 1.00 & 1.00 & 1.00 \\
\hline & 1.17 & $1.46^{* * * *}$ & $2.11^{*}$ & 1.28 & 2.18 & $1.33^{* *}$ & 1.08 & $1.81^{*}$ & 1.11 & 1.18 & 1.18 & 0.58 & $1.78^{*}$ \\
\hline \multirow{2}{*}{ zsome secondary } & $\begin{array}{l}(0.85-1.62) \\
1.46^{* *}\end{array}$ & $\begin{array}{l}(1.30-1.63) \\
2.21^{* * *}\end{array}$ & $\begin{array}{l}(1.01-4.41) \\
1.66^{*}\end{array}$ & $\begin{array}{l}(0.95-1.74) \\
2.98^{* * * *}\end{array}$ & $\begin{array}{l}(0.46-10.45) \\
3.37\end{array}$ & $\begin{array}{l}(1.1212-1.57) \\
1.92^{* * *}\end{array}$ & $\begin{array}{l}(0.226-4.46) \\
2.94\end{array}$ & $\begin{array}{l}(1.144-2.85) \\
3.06^{* * *}\end{array}$ & $\begin{array}{l}(0.89-1.38) \\
1.63^{* * *}\end{array}$ & $\begin{array}{l}(0.46-3.04) \\
1.66\end{array}$ & $\begin{array}{l}(0.81-1.71) \\
1.96 * * *\end{array}$ & $\begin{array}{l}(0.11-3.05) \\
0.70\end{array}$ & $\begin{array}{l}(1.10-2.91 .91) \\
2.92^{* * *}\end{array}$ \\
\hline & $(1.16-1.85)$ & $(2.03-2.40)$ & $(1.11-2.49)$ & $\begin{array}{l}2.90 \\
(2.20-4.04)\end{array}$ & $(0.73-15.62)$ & $(1.57-2.35)$ & $(0.84-10.23)$ & $\begin{array}{l}3.00 \\
(2.33-4.04)\end{array}$ & $(1.36-1.95)$ & $(0.81-3.38)$ & $(1.44-2.66)$ & $(0.18-2.72)$ & $(1.90-4.50)$ \\
\hline \multicolumn{2}{|l|}{ Wealth quintile } & & & & & & & & & & & & \\
\hline \multirow{3}{*}{$\begin{array}{l}\text { Poorest(rel) } \\
\text { Poor }\end{array}$} & 1.00 & 1.00 & 1.00 & 1.00 & 1.00 & 1.00 & 1.00 & 1.00 & 1.00 & 1.00 & 1.00 & 1.00 & 1.00 \\
\hline & 1.18 & $1.31^{* * *}$ & 2.43 & $1.38^{*}$ & 0.32 & 0.84 & 0.62 & 0.78 & $1.42^{*}$ & $25.39^{* *}$ & 1.26 & 1.15 & \\
\hline & $(0.84-1.67)$ & $(1.13-1.52)$ & $(0.89-6.61)$ & $(1.04-1.83)$ & $(0.06-1.64)$ & $(0.68-1.03)$ & $(0.19-2.04)$ & $(0.45-1.36)$ & $(1.09-1.87)$ & $(2.92-221.11)$ & $(0.98-1.63)$ & $(0.25-5.21)$ & $(0.89-2.73)$ \\
\hline \multirow[t]{2}{*}{ Middle } & 1.27 & $1.44^{* * *}$ & $3.50^{*}$ & $1.52^{* *}$ & 0.75 & 0.89 & 0.83 & 1.30 & $1.96^{* * *}$ & $37.09^{* * *}$ & $1.46 *$ & 2.97 & $2.10^{*}$ \\
\hline & $(0.90-1.79)$ & $(1.22-1.70)$ & $(1.33-9.23)$ & $(1.13-2.05)$ & $(0.14-4.12)$ & $(0.73-1.09)$ & $(0.23-3.05)$ & $(0.85-1.98)$ & $(1.48-2.60)$ & $(4.57-301.33)$ & $(1.12-1.90)$ & $(0.87-10.17)$ & $(1.18-3.72)$ \\
\hline Rich & $1.74^{* *}$ & $1.90^{* * *}$ & $4.91^{* * *}$ & $2.30^{* * * *}$ & 0.34 & 1.13 & 2.26 & $1.63^{*}$ & $2.24^{* * * *}$ & $114.25^{* * *}$ & $1.61^{* * * *}$ & 2.63 & $2.74^{* * *}$ \\
\hline & $(1.22-2.48)$ & $(1.60-2.25)$ & $(1.91-12.61)$ & $(1.70-3.12)$ & $(0.05-2.27)$ & $(0.87-1.45)$ & $(0.59-8.70)$ & $(1.07-2.47)$ & $(1.67-3.00)$ & (14.49-900.63) & $(1.24-2.10)$ & $(0.66-10.45)$ & $(1.57-4.76)$ \\
\hline Richest & $2.52^{* * *}$ & $2.81^{* * *}$ & $7.69^{* * *}$ & $2.94^{* * *}$ & 0.42 & $1.58^{*}$ & 2.41 & $2.94^{* * *}$ & $2.57^{* * *}$ & $68.59^{* * *}$ & $2.50^{* * *}$ & 3.12 & $4.56^{* * *}$ \\
\hline I cation & $(1.73-3.67)$ & $(2.36-3.34)$ & $(2.88-20.56)$ & $(2.17-3.98)$ & $(0.05-3.19)$ & $(1.09-2.29)$ & $(0.50-11.61)$ & $(1.73-4.98)$ & $(1.89-3.50)$ & $(8.32-565.14)$ & $(1.91-3.26)$ & $(0.83-11.75)$ & $(2.47-8.42)$ \\
\hline Rural (ref) & 100 & 100 & & 100 & & & & & & & & & 0.64 \\
\hline $\begin{array}{l}\text { Urban } \\
\text { Und }\end{array}$ & 0.92 & $1.22^{* * *}$ & 1.26 & 1.22 & 3.04 & 1.02 & 0.50 & 1.05 & 1.07 & 1.82 & 0.89 & 0.46 & 0.64 \\
\hline & $(0.65-1.32)$ & $(1.09-1.37)$ & $(0.80-1.98)$ & $(1.00-1.49)$ & $(0.99-9.32)$ & $(0.74-1.41)$ & $(0.12-2.03)$ & $(0.65-1.68)$ & $(0.88-1.29)$ & $(1.00-3.32)$ & $(0.74-1.08)$ & $(0.20-1.04)$ & $(0.31-1.33)$ \\
\hline F-statistic for regional & & & & & & & & & & & & & \\
\hline$N^{\text {indicators }}$ & $\begin{array}{c}9.33 \\
16805\end{array}$ & $\begin{array}{r}34.12 \\
124.151\end{array}$ & $\begin{array}{r}9.57 \\
91.009\end{array}$ & $\begin{array}{r}8.30 \\
32.788\end{array}$ & $\begin{array}{r}2.17 \\
30,702\end{array}$ & $\begin{array}{l}13.51 \\
6995\end{array}$ & $\begin{array}{l}1.00 \\
6459\end{array}$ & $\begin{array}{c}0.80 \\
10.542\end{array}$ & $\begin{array}{c}14.70 \\
10,005\end{array}$ & $\begin{array}{l}3.27 \\
10,005\end{array}$ & $\begin{array}{l}13.95 \\
13.544\end{array}$ & $\begin{array}{l}0.87 \\
9.448\end{array}$ & $\begin{array}{c}10.83 \\
13.137\end{array}$ \\
\hline
\end{tabular}


WEB APPENDIX TABLE 6. Odds ratios (and 95\% confidence intervals) from logistic regression analyses assessing associations between women's characteristics and having heard of or having ever used emergency contraception, Europe and West Asia

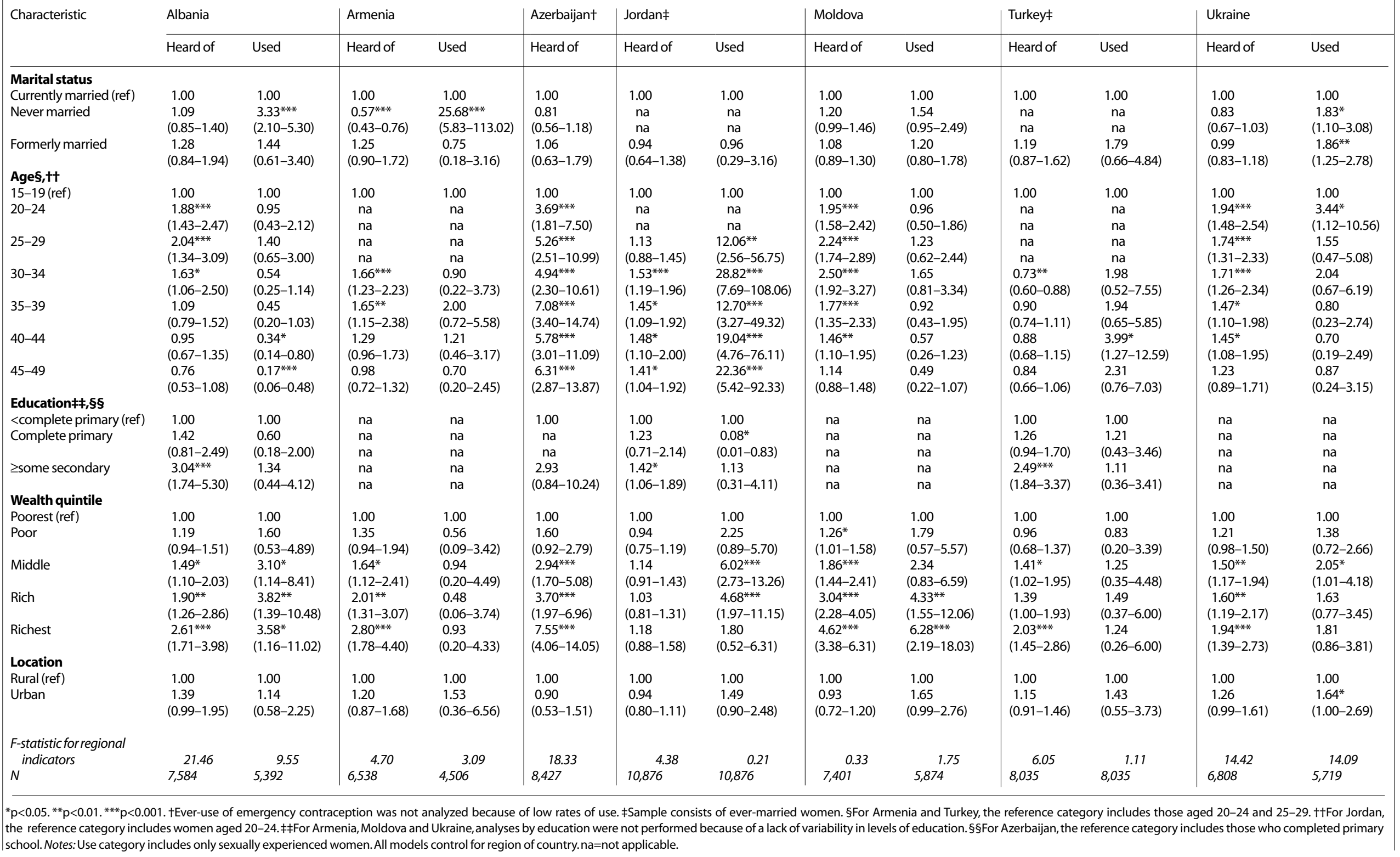


WEB APPENDIX TABLE 7. Odds ratios (and 95\% confidence intervals) from logistic regression analyses assessing associations between women's characteristics and having heard of or having ever used emergency contraception, Latin America and the Caribbean

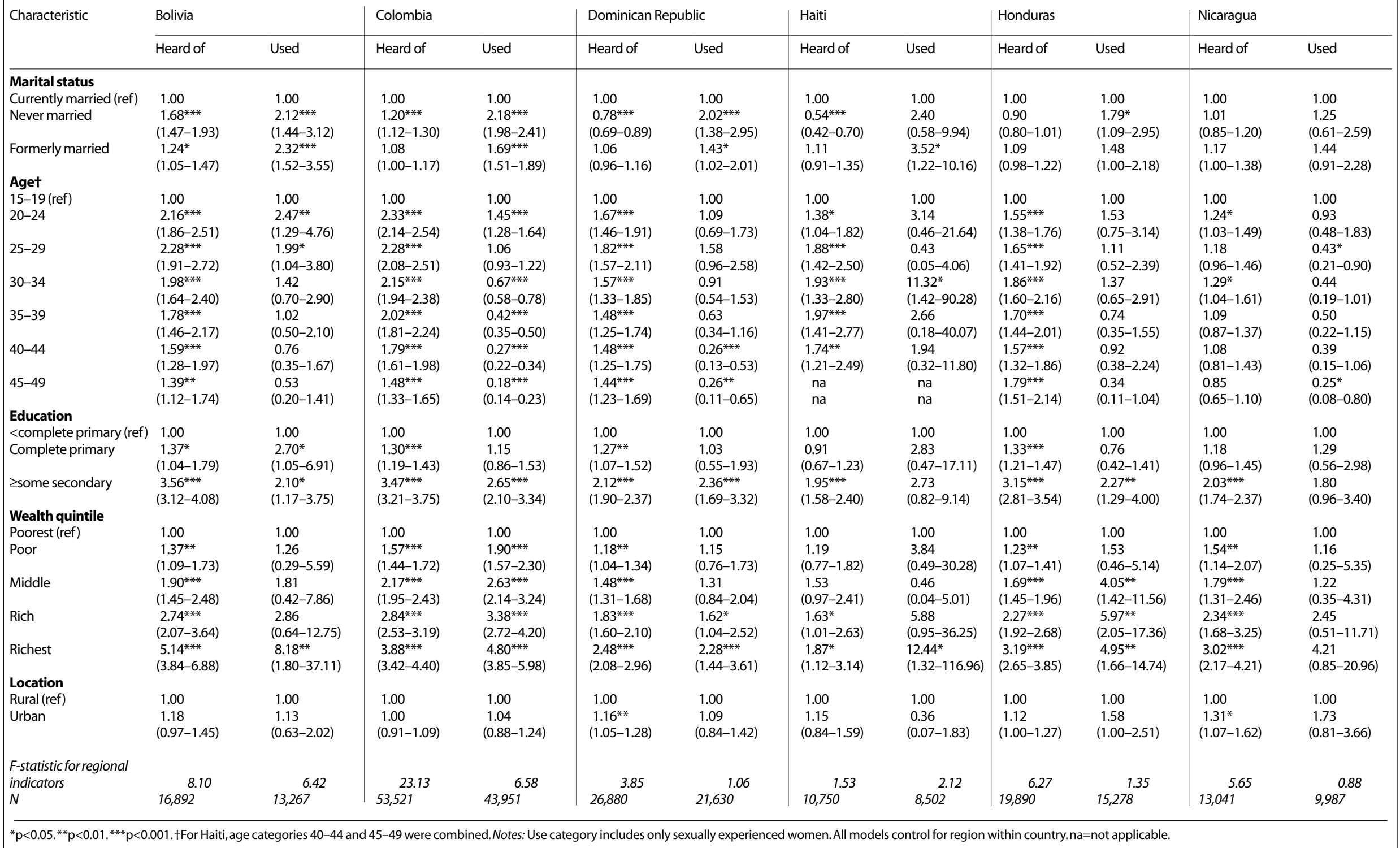

